\title{
BONANZACARPUM SPRUNGERORUM SP. NOV. - A BIZARRE FRUIT FROM THE EOCENE GREEN RIVER FORMATION IN UTAH, USA
}

\author{
STEVEN R. MANCHESTER ${ }^{1, *}$, TERRY A. LOTT $^{1}$ \\ ${ }^{1}$ Florida Museum of Natural History, Dickinson Hall, 1659 Museum Road, Gainesville, Florida 32611-7800, USA; e-mail: steven@flmnh.ufl.edu, \\ lott@flmnh.ufl.edu. \\ *corresponding author
}

Manchester, S. R., Lott, T. A. (2019): Bonanzacarpum sprungerorum sp. nov. - a bizarre fruit from the Eocene Green River Formation in Utah, USA. - Fossil Imprint, 75(1): 281-288, Praha. ISSN 2533-4050 (print), ISSN 2533-4069 (on-line).

\begin{abstract}
Shales of the early middle Eocene Parachute Creek Member of the Green River Formation in Utah, western USA, have yielded a large number of fossil plant remains with abundant Platanaceae, Salicaceae, and Ulmaceae, but many of the constituents of this flora remain indeterminate. Here we present a new fruit type based on distinctive sedimentary molds investigated by reflected light and $\mu \mathrm{CT}$ scanning. The structures are oblate woody fruits, about $18-26 \mathrm{~mm}$ wide but only 2-4 mm high, but partially flattened by compression within the sediment. In transverse view they are rounded-polygonal, with 5-6 sides. In lateral view the locule is dome-shaped with 7 to 11 obpyriform grooves radiating from the center of the basal wall. Three-dimensional imaging and both physical and digital sections indicate that the fruits were circumscissile capsules. Although analogous fruits occur in the Lecythidaceae A.Rich., Bonanzacarpum sprungerorum sp. nov. fruits are much smaller and lack the prominent woody pedicel and corresponding basal scar that characterizes that family. Hence, the systematic position of $B$. sprungerorum remains uncertain.
\end{abstract}

Key words: fossil fruits, circumscissile capsules, Palaeogene, extinct, micro-CT scanning

Received: April 17, 2019 | Accepted: June 12, 2019 | Issued: November 25, 2019

\section{Introduction}

Lacustrine shales of the early to middle Eocene Parachute Creek Member of the Green River Formation in Utah and Colorado are well known for abundant fossil leaves (Knowlton 1923, Cockerell 1925, Brown 1929, 1934, MacGinitie 1969). Occasionally reproductive remains such as flowers and fruits are also preserved, for example in Ulmaceae Mirb. (Cedrelospermum SAPORTA; Manchester 1989), Salicaceae Mirb. (Populus L. and Pseudosalix L.D.Boucher, MANCHESTER et JudD; Boucher et al. 2003, Manchester et al. 2006) and Sapindaceae (Koelreuteria LAXм.; Wang et al. 2013), but many other fruit and seed remains are still not described. The identification of these Eocene fossils is complicated by the occurrence of extinct as well as extant genera, and even those that represent extant genera often have their closest relatives living in other regions today.

Here we introduce an unusual type of fruit found in shales near Bonanza, Utah. Our understanding of these curiosities previously was limited by the difficulty of documenting features hidden within the sediment. Application of micro$\mathrm{CT}$ scanning $(\mu \mathrm{CT})$ now provides improved documentation of the morphology. Although the systematic affinities remain uncertain, it seems worthwhile to place them on record in the hope that their relationships may become clear with future work. This fruit type appears to have been endemic to the region and became extinct due to post-Eocene climatic cooling.

\section{Materials and methods}

The fruits in question are found at several localities of the Parachute Creek Member of the Green River Formation in eastern Utah near the towns of Bonanza and Watson in shales considered to be early Uintan, about $47 \mathrm{Ma}$ (Smith et al. 2008). The fruits occur in a horizon that is rich in fossil plants which has been traced laterally along strike for several miles. Specimens were collected by Mike and Sandra Sprunger, Bruce Handley, Kirk Johnson and the first author, and deposited in the collections of the University of California Museum of Paleontology, Berkeley, California (UCMP), Denver Museum of Nature and Science, Denver, Colorado (DMNH), and Florida Museum of Natural History, at the University of Florida, Gainesville Florida (UF). Altogether, 21 specimens were studied (see Appendix). The main localities are UF 18054 (Watson II; 39 53'40.76" N, $109^{\circ} 8^{\prime} 42.31^{\prime \prime} \mathrm{W}$ ), UF 18116 (Watson IV; 3956'20.33" N, 

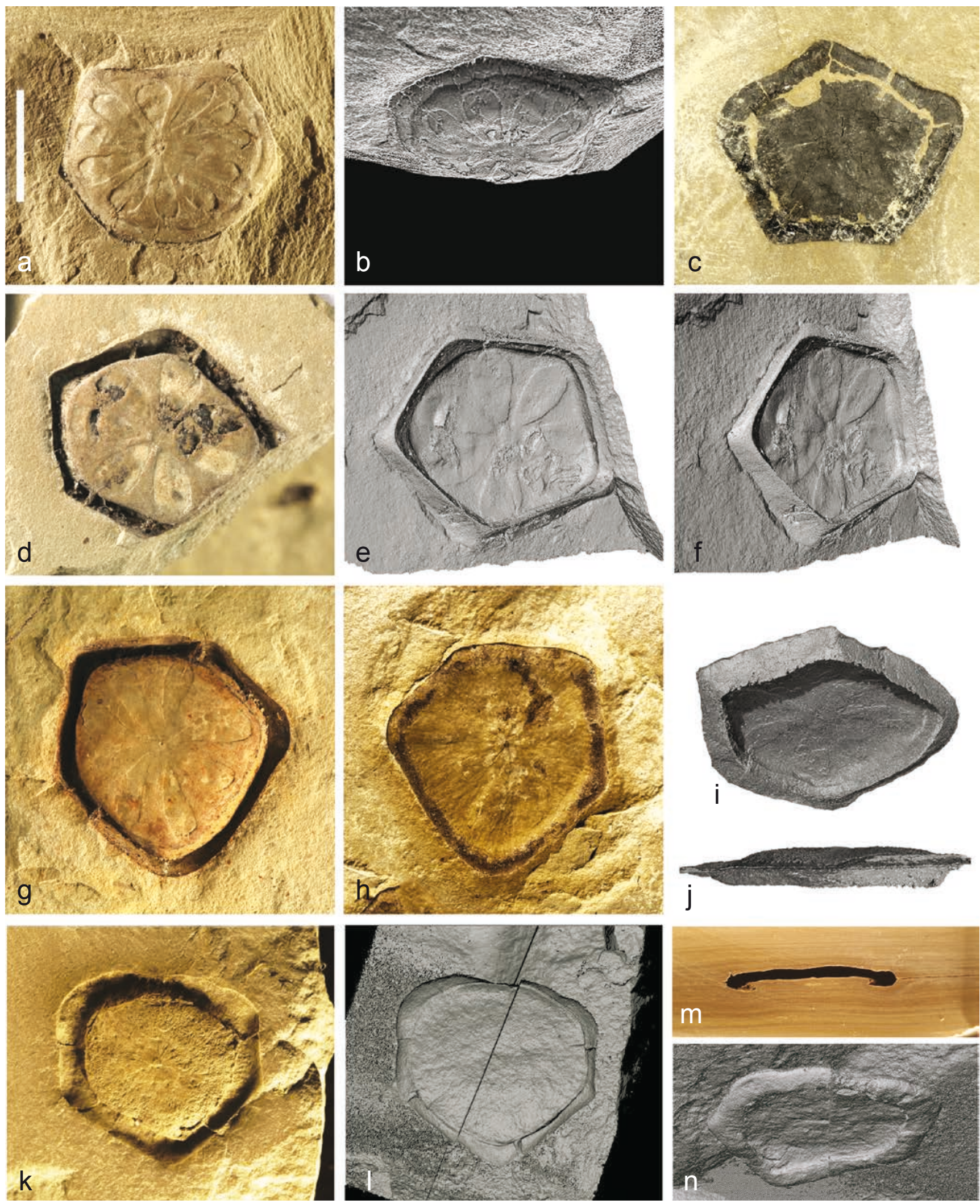

Text-fig. 1. Bonanzacarpum sprungerorum gen. et sp. nov., fruits. a, b) Mold of inner surface of the basal portion of a fruit with 11 radiating placentae, holotype, UF 18054-55045. a) Transverse view, reflected light. b) Oblique lateral view showing domed appearance and recessed placentae, surface rendering from micro-CT scan data. c) Transversely compressed pentagonal specimen, reflected light, UF 18118-22840. d-f) Mold of basal portion of a fruit with 7 radiating placentae, UCMP PB02016-201240. d) Transverse view, reflected light. e, f) Surface renderings of same specimen as viewed through the shale from behind, showing sharp edge of the surrounding wall from which the operculum is inferred to have been shed. Specimen rotated with two views: nearly transverse and oblique-lateral, showing placentae slightly raised within the locule. $\mathrm{g}$-j) Upper and lower counterpart surfaces of the basal portion of a fruit, UCMP PB02016-201239. g) Reflected light of locule cast of basal portion of fruit. h) Reflected light image of the counterpart from ( $g$ ), representing the basal endocarp surface. $i, j$ ) Micro-CT surface rendering of the specimen in $(\mathrm{g}, \mathrm{h})$, showing short, button-shaped outline, and open apex interpreted to indicate that it is dehiscent with the operculum and 
$109^{\circ} 7^{\prime} 47.68^{\prime \prime} \mathrm{W}$ ), and UF 18118 (Watson VIII; 3950'55.34" $\left.\mathrm{N}, 109^{\circ} 10^{\prime} 3.73^{\prime \prime} \mathrm{W}\right)$. A new species name is registered in the Plant Fossil Names Registry (https://www.plantfossilnames. org), which is hosted and operated by the National Museum, Prague, for the International Organisation of Palaeobotany (IOP), each with a unique registry number.

Specimens were photographed under low oblique lighting using a Canon Rebel XSi camera fitted with a DFS $60 \mathrm{~mm}$ macro lens. Two specimens for which both upper and lower counterpart shale pieces were available were temporarily reassembled then sawn with an annular saw to document the shape of the compressed fruit in lateral view. Subsequently, as computer tomographic technology became available, specimens were x-rayed with a GE Phoenix V|tome|xm240 micro-CT Scanner at the Nanoscale Research Center, University of Florida, Gainesville, FL. We used a Tungsten reflection target, with a voltage of $200 \mathrm{kV}$ and current of $140 \mu \mathrm{A}$ with 2250 images of a single specimen for voxel size of $31 \mu \mathrm{m}$. Datasets from micro-CT were analyzed with Avizo 9.0 Lite (FEI Visualization Science Group, Bordeaux, France), and Meshlab to provide volume renderings, isosurface renderings and virtual sections. Examples of the most informative micro-CT 3-D datasets and movies are accessible at Morphosource.org (key word Bonanzacarpum).

\section{Systematic palaeobotany}

\section{Subdivision Angiospermae LindLey, 1830 Rosopsida BATSCH, 1788 (eudicots) Incertae familiae}

\section{Genus Bonanzacarpum gen. nov.}

Ty p e. Bonanzacarpum sprungerorum sp. nov.

Plant Fossil Names Registry Number. PFN000563 (for new genus).

Ety m o logy. Bonanza (the nearest town to the fossil occurrences in northeastern Utah) plus carpum (fruit).

D i a g n o s is . Fruit a tabular 4-6 sided circumscissile capsule. Capsule unilocular, with closely fitting operculum. Basal surface of locule with 7-11 obpyriform raised areas radiating from a central point and pointing proximally.

\section{Bonanzacarpum sprungerorum sp. nov. Text-figs 1-3}

H o l o ty pe. UF 18054-55045 (Text-fig. 1a, b) housed in Florida Museum of Natural History.

$P$ a ratypes. UCMP PB02016-201239, UCMP PB02016-201240, UF 15753-78205, UF 18054-22886, 55045,55055 .

Plant Fossil Names Registry Number. PFN000564 (for new species).
Etymology. The species name honors Mike and Sandra Sprunger who collected and donated some of the finest examples.

Type locality. Vicinity of Bonanza, Utah, USA (UF locality 18054: 39 $53^{\prime} 40.76^{\prime \prime} \mathrm{N}, 109^{\circ} 8^{\prime} 42.31^{\prime \prime} \mathrm{W}$ ).

Type horizon and age. The Parachute Creek Member, early to middle Eocene, ca. $47 \mathrm{Ma}$.

D i a g o s is. Fruit a tabular, button-shaped circumscissile capsule, rounded-polygonal in transverse section with 4 to 6 equal to unequal sides. Capsule unilocular, circumscissile with an apical operculum closely fitting like a stopper. Lateral walls smooth, straight. Basal surface of locule with 7-11 smooth, obpyriform, slightly raised areas radiating from a central point. Obpyriform areas pointed proximally, with somewhat convex lateral margins and round distal margins. Obpyriform areas with corresponding cycle of smaller indentations on the basal external surface.

Description. Fruits tabular, button-shaped circumscissile capsules 2-4 $\mathrm{mm}$ high and $18-30 \mathrm{~mm}$ in diameter, rounded-polygonal in transverse section with 4 to 6 equal to unequal sides. Capsule unilocular, circumscissile with an apical operculum closely conforming in shape and size to that of the fruit as viewed transversely, and closely fitting like a stopper. Lateral walls smooth, straight. Basal surface of locule with 7-11 smooth, obpyriform, slightly raised areas radiating from a central point. Obpyriform areas are pointed proximally, with somewhat convex lateral margins and round distal margins, 7-9 mm long, and 1.3$3.0 \mathrm{~mm}$ wide. These marks are not evident from the outer surface of the fruit, but a corresponding cycle of smaller indentations occurs on the basal external surface. Fruit wall 1.2-1.6 mm thick, composed of sclerenchymatous tissue.

\section{Discussion}

Although these fruits have been observed over some decades and are present in palaeobotanical collections of at least three museums, they have not received attention in the literature. It was difficult to decipher the original morphology because details of the surfaces were obscured by coaly matter often adhering to the molds. The fruits are inferred to have been oblate (shorter in axial direction than in width), because they are never preserved in lateral orientation, but always lie in basal-apical orientation. They have been somewhat crushed transversely, as shown by radial fracture marks (Text-figs 2a, j, 1, 3d). For some time, it was a mystery why the star shaped radial pattern of obpyriform marks is seen on some specimens (e.g. Text-fig. 1a, d, g) but not others. The recovery of additional information by means of x-ray technology has facilitated a clearer understanding of the morphology. The radiating ridges forming the star pattern are only on the inside of the lower surface of the woody capsule (Text-figs 1a, d-g, 2b).

contents shed. k-n) UF 18054-55052. k) Impression of apical side of a fruit. I) Micro-CT surface rendering of the same specimen. m) Physical longitudinal section through the fruit (both counterpart pieces reassembled) by reflected light. n) Micro-CT surface rendering viewed from beneath. Scale bar in $(a)=10 \mathrm{~mm}$, applies also to $(\mathbf{b}-\mathbf{n})$. 

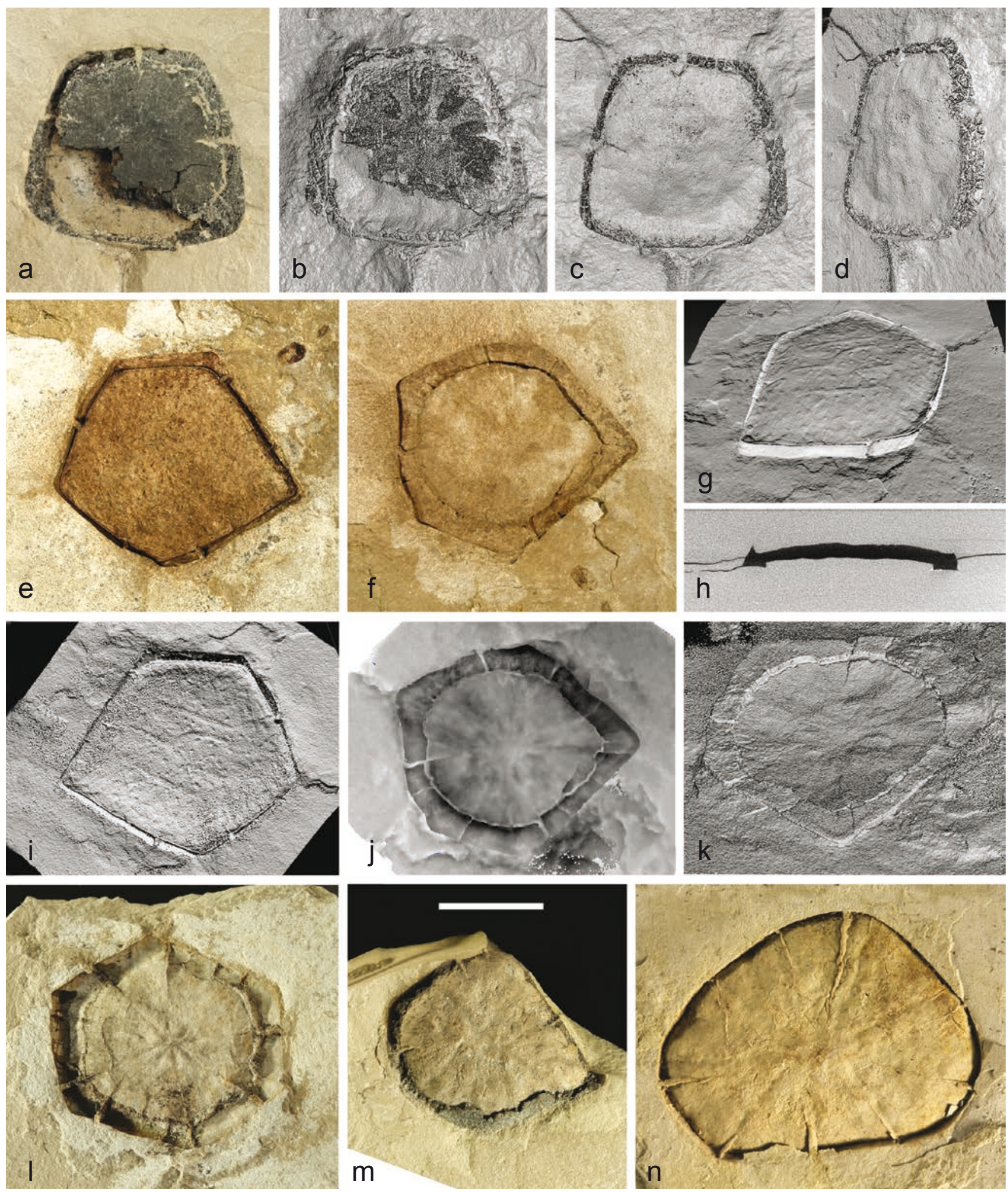

Text-fig. 2. Bonanzacarpum sprungerorum gen. et sp. nov., fruits. a-d) UF 18054-62091. a) Compressed quadrangular fruit with coalified remains of endocarp, reflected light microscopy. b) Same specimen by micro-CT scan, volume rendering with coalified material rendered partly translucent showing radiating placental ridges. c) Same specimen, isosurface generated from micro-CT scan data, showing smooth apical surface. d) Same viewed laterally showing relatively short side walls of the fruit. e-k) UF 1805455050. Pentagonal fruit. e) Impression of apical surface by reflected light. f) Counterpart impression of same specimen by reflected light, showing central collapsed portion of wall, and thick lateral walls. g) Surface rendering from micro-CT data. Oblique-lateral view of apical surface showing straight side walls and marginal fissure defining the operculum. h) Digital longitudinal section through the complete specimens (both counterparts assembled), with black area representing the space originally occupied by the fruit. Note the width much greater than height. i) Transverse view of the apical surface from (e). j) Depth mapping of the complete specimen, showing whorl of 8 depressions on lower surface. $k$ ) Oblique view of surface rendering representing the basal side of the fruit, with evident collapse of some of the basal wall. I) Hexagonal fruit by reflected light, with obvious stress fractures, and central whorl of depressions, UF 18054-55053. m) Transverse view of locule cast with coalified remains of endocarp at lower margin, UF 18054-55046. $n$ ) Largest specimen, UCMP PB02016-391009. Scale bar in $(\mathrm{m})=10 \mathrm{~mm}$, applies to (a-l, $\mathbf{n})$. 

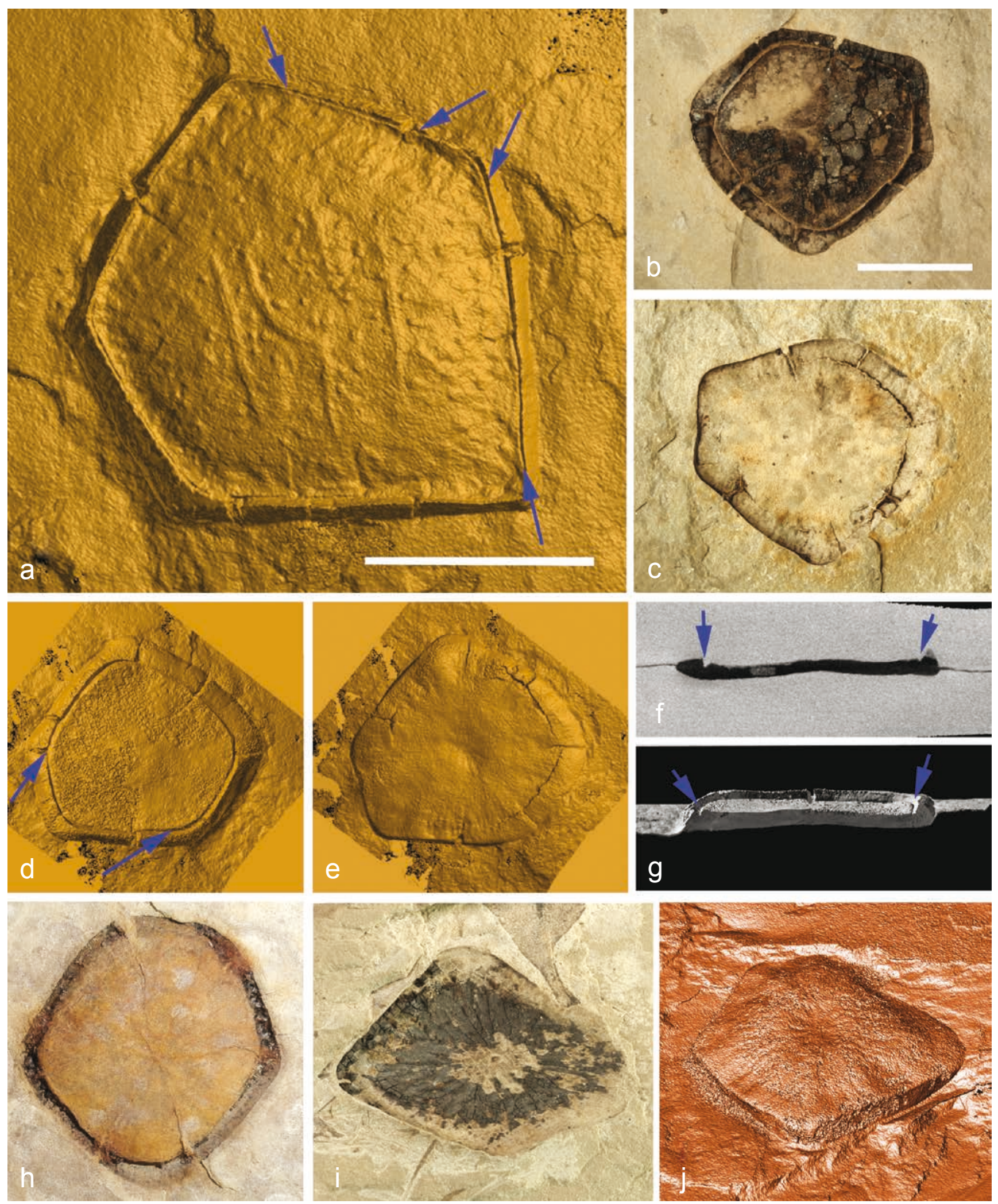

Text-fig. 3. Bonanzacarpum sprungerorum gen. et sp. nov., fruits. a) Apical view of UF 18054-55050, showing the peripheral crack (arrows) delineating the apical operculum. Isosurface rendering from micro-CT scan data. b-g) UF 18054-55051. b) Viewing toward the apex, impression containing coalified remains of the endocarp. c) Counterpart specimen, viewed toward the base, impression with subsidence cracks of the endocarp. d, e) Isosurface rendering from micro-CT scan of the specimen in (b, c). Note the clear delineation of operculum in (d) (arrows) and subsidence cracks in (e). f) Digital longitudinal section with arrows indicating the margin of operculum. g) Surface rendering in longitudinal section with arrows indicating margin of operculum. h) Rounded pentangular fruit with convex surface of the base of the locule, DMNH 22486, loc. 323. i) UF 18054-55054, reflected light of concave basal impression with adherent coalified material. j) Surface rendering of specimen in (i), based on micro-CT scan data, showing straight lateral walls and domed base. Scale bar in (a), (b) $=10 \mathrm{~mm}$, bar in (b) applies also to (c-j). 
The wall of Bonanzacarpum fruits, about 1.2-1.6 mm thick, is usually coalified, indicating that it was probably composed of hard sclerenchymatous tissue - likely the endocarp. If there were surrounding fleshy layers, they have not preserved. In some specimens the coalified part has disintegrated, leaving only the surface mold in the shale. When discovered during the process of splitting shale in the field, both upper and lower halves of the fossil are revealed that appear almost as mirror images (part and counterpart). Sometimes both of these halves were retained but in other cases only one of the two counterparts is available. The more informative specimens are those for which both counterparts were retained. Among such specimens, some appear to represent fruits that were complete and unopened at the time of deposition with both base and apex intact, while others appear to represent only the basal or apical member of the capsule.

Among the specimens that appear to be complete fruits (e.g. Text-figs $1 \mathrm{n}, 2 \mathrm{e}, \mathrm{f}$ ), one side is smooth to slightly wrinkled, lacking any central marking that might represent pedicel or style, but shows a prominent marginal groove or crack that appears to be the position along which the operculum would separate (Text-figs 11, 2g, 3a, d). The opposite side bears a small central depression surrounded by 7 to 11 radiating symmetrical obpyriform ridges on the locule surface, interpreted as placentae (e.g. Text-fig. 1a, $\mathrm{g})$. If this orientation is correct, then the placentae appear to have been basal to lateral but not apical. The placentae vary in number (7, 8 and 11 were observed). They are found on the inside of the fruit wall, slightly protruding into the locule. Because these radiating marks surround a small central scar, this is assumed to be the basal portion of the fruit, through which vasculature from the pedicel would have passed. There is no indication of finer marks to indicate multiple seeds attached to each ridge, so perhaps there was one seed per ridge. Although the radiating marks resemble somewhat the stigmatic slits of Nymphaeaceae SALISB. and Papaveraceae Juss., they are confined to the inner surface of the locule, not expressed on the external surface of the fruit. Also, the marks cannot be considered dehiscence slits because they do not penetrate the fruit wall. If correctly interpreted as placental scars, then we can infer that they developed from syncarpous ovaries with 7 to 11 carpels.

In micro-CT renderings, a fine marginal crack is seen separating the operculum from the lateral walls of the fruits (Text-fig. 3a, d). Thus, it seems likely that these fruits represent circumscissile capsules with a single apical valve. Because there is no indication of style nor pedicel scar on the external surface of the preserved remains, it may be inferred that a fleshy layer, which would have borne these structures, was originally present but not preserved.

Oblate woody endocarps of similar external form and dimensions occur in Poupartia Comm. ex Juss. and Antrocaryon PIERRE of the Anacardiaceae R.BR. subfamily Spondioideae (Herrera et al. 2018), but the fruits in that group are multilocular with thick septa, unlike Bonanzacarpum. The operculate construction of Bonanzacarpum fruits is most similar to that of some genera in the extant tropical family, Lecythidaceae. This family includes several genera with woody fruits having dehiscence by a circumscissile operculum (Prance and Mori 1978, 2003), as well as some genera with indehiscent fruits, but they have fewer carpels, ranging from 2 to 6 , compared to the 7 to 11 carpels inferred for Bonanzacarpum. In some genera of Lecythidaceae, such as Allantoma Miers, Cariniana CAsar., Couratari Aubl. and Corythophora R.KNUTH, the operculate fruits are very elongate and thus quite distinct from the oblate fossil capsules, but Eschweilera MART. ex DC. and Lecythis LoEFL. can have oblate fruits more similar to our fossils (see illustrations in Prance and Mori 1978). The radiating pattern of placental marks on the opercula of these extant genera shows some similarity to that seen in Bonanzacarpum fruits. The septa in Lecythis and related genera are very thin, thus giving the appearance of unilocular condition in fruit. It seems likely however, that these similarities reflect convergent evolution. Bonanzacarpum fruits lack any indication of a thick woody pedicel of the kind seen in Lecythidaceae, and the extant fruits reach much larger dimensions. Hence the affinities of these fossils do not appear to lie close to any known extant genus. Even the familial affinities remain mysterious.

\section{Restricted geographic and stratigraphic range}

The early to middle Eocene Green River Formation, deposited in three former great lakes, is well exposed in eastern Utah, western Colorado and southwestern Wyoming (Smith et al. 2008, Grande 2013), with fossil plant localities best known from the early Eocene Fossil Butte, Wilkins Peak and Laney Members in Wyoming (MacGinitie 1969, Wilf 2000, Grande 2013), and from the early middle Eocene Parachute Creek Member of Utah and Colorado (MacGinitie 1969, Johnson and Plumb 1995). The flora of the Parachute Creek Member is the most thoroughly documented (Knowlton 1923, Brown 1929, 1934, MacGinitie 1969), with many constituents found both in the localities of eastern Utah near Bonanza, and the sites of western Colorado near Douglas Pass. Despite intensive collection in both of these areas over many decades and lithologic similarities of the shales in both these areas, we have recovered Bonanzacarpum fruits only from the Bonanza area. Their apparent absence from the Colorado and Wyoming sites of the Green River Formation suggests that the range of this extinct plant was very localised. It is also absent from museum collections of similar age deposits of the Clarno flora in Oregon, the Okanogan highland floras of Washington and British Columbia, and from middle Eocene shales of central Europe, e.g. Messel (Wilde 1989, Collinson et al. 2012) and Eckfeld (Wilde and Frankenhäuser 1998). Possibly Bonanzacarpum was a narrow endemic. Other organs of the Bonanzacarpum plant, including leaves and flowers remain uncertain, but might be present among the unidentified plant material residing in collections from the Bonanza shales.

\section{Affinities of Eocene flora}

Eocene floras include a large number of genera that are readily recognized and assignable to modern families based on taxonomically diagnostic suites of morphological characters (Manchester 1994, Collinson et al. 2012). However, we cannot expect to assign every fossil to a particular modern clade. In some instances the available characters of a fossil taxon are insufficiently distinctive to assign to a particular modern 
clade because the same combination of characters occurs in more than one unrelated group. In other cases, the characters are highly distinctive, yet do not match to those known in any modern genus. Bonanzacarpum seems to belong to the latter category. Fossils of this kind are often excluded from publication because it can ruin one's reputation to put in print "I don't know what this is". Nevertheless, such fossils are an important part of the record, and their exclusion from former monographic treatments may give the false impression of modernity of the fossil assemblages from which they derive. We have focused on the familiar extant taxa that we can recognize easily, but usually set aside for some future date, the more difficult fossils.

\section{Acknowledgements}

We thank Bruce Handley for donating specimens to the University of California Museum of Paleontology (UCMP) which were consulted in this investigation. Kevin Nixon and Walter Judd provided guidance about possible affinities. For access to collections and curatorial assistance we thank Scott Wing and Jonathan Wingerath (United States National Museum), Diane Erwin (UCMP), Ian Miller (Denver Museum of Natural History) and Hongshan Wang (Florida Museum of Natural History). We thank the anonymous reviewers and the editors for final improvements to the text.

\section{References}

Boucher, L. D., Manchester, S. R., Judd, W. S. (2003): An extinct genus of Salicaceae based on twigs with attached flowers, fruits, and foliage from the Eocene Green River Formation of Utah and Colorado, USA. - American Journal of Botany, 90: 1389-1399.

https://doi.org/10.3732/ajb.90.9.1389

Brown, R. W. (1929): Additions to the flora of the Green River Formation. - U.S. Geological Survey Professional Paper, 154-J: 279-299. https://doi.org/10.3133/pp154J

Brown, R. W. (1934): The recognizable species of the Green River flora. - U.S. Geological Survey Professional Paper, 185-C: 44-77. https://doi.org/10.3133/pp185C

Cockerell, T. D. A. (1925): Plant and insect fossils from the Green River Formation of Colorado. - Proceedings of the U.S. National Museum, 66: 1-13. https://doi.org/10.5479/si.00963801.66-2556.1

Collinson, M. E., Manchester, S. R., Wilde, V. (2012): Fossil fruits and seeds of the Middle Eocene Messel biota, Germany. - Abhandlungen der Senckenberg Gesellschaft für Naturforschung, 570: 1-250.

Grande, L. (2013): Snapshots from deep time. The lost world of Fossil Lake. - University of Chicago Press, Chicago, Illinois, $425 \mathrm{pp}$. https://doi.org/10.7208/chicago/9780226922980.001.0001

Herrera, F., Mitchell, J. D., Pell, S. K., Collinson, M. E., Daly, D. C., Manchester, S. R. (2018): Fruit morphology and anatomy of the Spondioid Anacardiaceae. - Botanical Review, 84: 315-393.

https://doi.org/10.1007/s12229-018-9201-1
Johnson, K. R., Plumb, C. (1995): Plant Fossils from the Green River Formation at Douglas Pass, Colorado, and Bonanza, Utah. - In: Averett, W. R. (ed.), The Green River Formation in Piceance Creek and eastern Uinta Basins. Grand Junction Geological Society, Colorado, pp. 121-130.

Knowlton, F. H. (1923): Revision of the flora of the Green River Formation. - U.S. Geological Survey Professional Paper, 131: 133-182. https://doi.org/10.3133/pp131F

MacGinitie, H. D. (1969): The Eocene Green River flora of northwestern Colorado and northeastern Utah. - University of California Publications in Geological Sciences, 83: 1-203.

Manchester, S. R. (1989): Attached reproductive and vegetative remains of the extinct American-European genus Cedrelospermum (Ulmaceae) from the early Tertiary of Utah and Colorado, USA. - American Journal of Botany, 76: 256-276. https://doi.org/10.1002/j.1537-2197.1989.tb11309.x

Manchester, S. R. (1994): Fruits and seeds of the Middle Eocene Nut Beds flora, Clarno Formation, Oregon. Palaeontographica Americana, 58: 1-205.

Manchester, S. R., Judd, W. S., Handley, B. (2006): Foliage and fruits of early poplars (Salicaceae: Populus) from the Eocene of Utah, Colorado, and Wyoming. - International Journal of Plant Sciences, 167: 897-908. https://doi.org/10.1086/503918

Prance, G. T., Mori, S. A. (1978): Observations on the fruits and seeds of neotropical Lecythidaceae. - Brittonia, 30: 21-33. https://doi.org/10.2307/2806452

Prance, G. T., Mori, S. A. (2003): Lecythidaceae. - In: Kubitzki, K. (ed.), The families and genera of vascular plants. Vol. 6, Flowering plants dicotyledons: Celastrales, Oxalidales, Rosales, Cornales, Ericales. Springer, Berlin, pp. 221-232. https://doi.org/10.1007/978-3-662-07257-8_24

Smith, M. E., Carroll, A. R., Singer, B. S. (2008): Synoptic reconstruction of a major ancient lake system: Eocene Green River Formation, western United States. - Geological Society of America Bulletin, 120: 54-84. https://doi.org/10.1130/B26073.1

Wang, Q., Manchester, S. R., Gregor, H.-J., Shen, S., Li, Z.-Y. (2013): Fruits of Koelreuteria (Sapindaceae) from the Cenozoic throughout the northern hemisphere: Their ecological, evolutionary, and biogeographic implications. - American Journal of Botany, 100: 422-449. https://doi.org/10.3732/ajb.1200415

Wilde, V. (1989): Untersuchungen zur Systematik der Blattreste aus dem Mitteleozän der Grube Messel bei Darmstadt (Hessen, Bundesrepublik Deutschland).Courier Forschungsinstitut Senckenberg, 115: 1-213.

Wilde, V., Frankenhäuser, H. (1998): The Middle Eocene plant taphocoenosis from Eckfeld (Eifel, Germany). Review of Palaeobotany and Palynology, 101: 7-28. https://doi.org/10.1016/S0034-6667(97)00067-5

Wilf, P. (2000): Late Paleocene-Early Eocene climate changes in southwestern Wyoming: Paleobotanical analysis. Geological Society of America Bulletin, 112: 292-307. https://doi.org/10.1130/0016-7606(2000)112<292:L PECCI $>2.0 . \mathrm{CO} ; 2$ 


\section{Appendix}

Morphological characteristics of the examined specimens.

\begin{tabular}{|c|c|c|c|}
\hline Specimen & Endocarp outline & $\begin{array}{c}\text { Maximum endocarp } \\
\text { diameter }\end{array}$ & Additional characters \\
\hline UF 15753-78205 & pentagonal & $23 \mathrm{~mm}$ & 8 radiating obpyriform marks \\
\hline UF 18116-22886 & pentagonal & $20 \mathrm{~mm}$ & 11 radiating obpyriform marks \\
\hline UF $18118-22840$ & pentagonal & $23 \mathrm{~mm}$ & Coalification \\
\hline UF 18054-22806 & hexagonal & $26 \mathrm{~mm}$ & Both counterparts \\
\hline UF $18054-55045$ & hexagonal & $20 \mathrm{~mm}$ & $\begin{array}{l}\text { Convex impression with } 11 \text { obpyriform } \\
\text { depressions }\end{array}$ \\
\hline UF 18054-55046 & rounded pentagonal & $23 \mathrm{~mm}$ & $\begin{array}{l}\text { Convex impression with weak radial grooves and } \\
\text { adhering coalified material }\end{array}$ \\
\hline UF $18054-55047$ & pentagonal & $18 \mathrm{~mm}$ & Smallest specimen, coalification \\
\hline UF $18054-55048$ & pentagonal & $23 \mathrm{~mm}$ & Ca. 10 small radiating marks; coalification \\
\hline UF $18054-55050$ & pentagonal & $25 \mathrm{~mm}$ & Both counterparts \\
\hline UF 18054-55051 & pentagonal & $22 \mathrm{~mm}$ & Both counterparts \\
\hline UF $18054-55052$ & rounded pentagonal & $17 \mathrm{~mm}$ & $\begin{array}{l}\text { Both counterparts; one side is convex, other } \\
\text { concave }\end{array}$ \\
\hline UF $18054-55053$ & hexagonal & $26 \mathrm{~mm}$ & Convex impression \\
\hline UF 18054-55054 & rounded-quadrangular & $24.5 \mathrm{~mm}$ & $\begin{array}{l}\text { Concave impression with adhering carbon, central } \\
\text { depression (pedicel scar) }\end{array}$ \\
\hline UF $18054-55055$ & hexagonal & $22 \mathrm{~mm}$ & 12 radiating small elliptical marks in center \\
\hline UF 18054-55056 & pentagonal with one face longer & $22.5 \mathrm{~mm}$ & Several radiating obpyriform marks \\
\hline UF 18054-62091 & quadrangular with one side larger & $21 \mathrm{~mm}$ & 12 radial pyrform marks, coalification \\
\hline UCMP PB02016-201239 & pentagonal & $23 \mathrm{~mm}$ & $\begin{array}{l}8 \text { radiating obpyriform marks; upper and lower } \\
\text { counterpart surfaces of the basal portion of a fruit }\end{array}$ \\
\hline UCMP PB02016-201240 & pentagonal & $22 \mathrm{~mm}$ & $\begin{array}{l}\text { Cast of basal portion of a fruit with } 7 \text { radiating } \\
\text { obpyriform marks }\end{array}$ \\
\hline DMNH $22486 \quad$ loc 323 & pentagonal & $22 \mathrm{~mm}$ & 8 radiating obpyriform marks \\
\hline DMNH $22487 \quad$ loc 323 & hexagonal & $21 \mathrm{~mm}$ & Both counterparts, coalification \\
\hline UCMP PB02016-391009 & rounded pentagonal & $30 \mathrm{~mm}$ & Largest specimen \\
\hline
\end{tabular}

